\title{
In Search of a Legal Solution to the Weaponisation of Space: A Russian Perspective
}

\author{
Author: Yevgeny K. Zvedre
}

To cite this article: Zvedre, Y. K. (2020). In Search of a Legal Solution to the Weaponisation of Space: A Russian Perspective. National Security Journal. doi:10.36878/nsj20200201.06

To link to this article: https://doi.org/10.36878/nsj20200201.06

View CrossRef data: https://search.crossref.org/?q=10.36878\%2Fnsj20200201.06 


\title{
IN SEARCH OF A LEGAL SOLUTION TO THE WEAPONISATION OF SPACE: A RUSSIAN PERSPECTIVE
}

\author{
Yevgeny K. Zvedre ${ }^{1}$
}

\begin{abstract}
This article is primarily focused on the diplomatic efforts aimed at preventing the weaponisation of outer space, or development of weapon systems designed to destroy targets, either orbital or terrestrial, or from the ground in outer space. Along with that, a number of anti-satellite weapon projects that both the United States (US) and the Soviet Union/Russia have been developing since the 1950s are briefly described as examples of their military competition in space. Highlighted is the work that has been done within the United Nations (UN) context to develop a corpus of universal principles and norms governing international exploration of outer space as the common heritage of humankind, free from the use of force. The author also highlights the positive role that arms control treaties have been playing in preventing deployment of weapons in space. Particular emphasis is given to the potential consequences for global security should attack weapons appear in outer space, and to the importance of a further targeted effort by the international community to work out additional regulations strengthening space security. In this regard, draft treaties on the prevention of weapons in space introduced by Russia and China, and the European Union's International Code of conduct for Space are emphasised.
\end{abstract}

Keywords: weaponisation of space, principles and norms governing peaceful exploration of outer space, antisatellite weapon systems, further development of international space law, initiatives to prevent deployment of attack weapons in space, space security.

1 Yevgeny Zvedre is a retired Russian career diplomat with more than 35 years experience in the Soviet and Russian diplomatic services. His background is in scientific diplomacy, nonproliferation, and international security issues. In the 2000s he served as Science and Technology Attaché at the Embassy of the Russian Federation in Washington, D.C. and in the 1980s and 1990s was involved in strategic arms control negotiations, ABM Treaty compliance issues and international space cooperation. Prior to this he worked on regional affairs with a focus on Southeast Asia. Mr. Zvedre has authored articles on space, missile non-proliferation, and export controls. 
In the late 1950s the Cold War between the Soviet Union and the United States (US) was rapidly expanding. The flights of the first satellites and appearance of intercontinental ballistic missiles (ICBMs) made the threat of spreading the arms race outside of Earth's atmosphere quite real. The leaders of both superpowers, fully understanding the military and political opportunities that missile technologies offered, gave primary emphasis in their space efforts to national security objectives. Outer space was turning into an area of active competition, thus, making the appearance in Earth's orbit of weapon systems designed to destroy or disrupt objects in outer space, and on the ground (from space), distinct possibilities.

Henceforth, issues related to the appearance of such attack weapon systems have been occupying a prominent place in practically all doctrinal national security documents of both countries. For example, current Russian Federation Military Doctrine considers "the intention to deploy weapons in space" to be one of the "major external military threats" facing Russia. This threat viewed within the context of broader threats, that is outlined as the "deployment of strategic missile defense systems undermining global stability and violating the established balance of forces related to nuclear missiles, implementation of the global strike concept, as well as deployment of strategic non-nuclear systems of high-precision weapons; proliferation of weapons of mass destruction, missiles and missile technologies". ${ }^{1}$ Alternatively, the conceptual approaches of the US towards space exploration have always included provisions emphasising the need to strengthen dominance and guarantee leadership in space based on the freedom of action in defending national security interests.

Nowadays, outer space is an increasingly vital domain of military activities, and military power is increasingly reliant on the use of space technology. Therefore, the term militarisation of outer space is widespread and often used to describe the use of space for military purposes. This comprises the role space military assets are playing in strategic planning and maintaining the strategic nuclear balance, ensuring transparency and predictability of military activity and modern combat operations. They include spacecraft designed for military command and control, reconnaissance, surveillance, communications, radar, navigation, cartographic and meteorological support, and ballistic missile attack warning.

It is generally recognised that the existence of such military space assets does not have a negative impact on the global strategic situation. Their functioning contributes to better transparency and predictability and ensures prevention of dangerous incidents that may occur during daily activities of the armed forces, guarantees arms control compliance and verification. Importantly, the existing norms of international space law do not impose any restrictions on development, testing and deployment of the military assets in outer space. 
On the other hand, the weaponisation of space refers to a more aggressive and offensive use of space assets for development, testing, and deployment of weapon systems designed to destroy targets, either terrestrial or in low-Earth orbit, or from the ground in outer space.

\section{Outer Space as a potential battlefield}

Starting from the late 1950s, the Soviet Union and the US focused significant resources on intensive development of combat space assets while contemplating outer space as a potential battlefield. They planned, tested, and even partially deployed various types of space weapons. They included weapons designed to incapacitate or destroy satellites, i.e. anti-satellite (ASAT) weapons, and anti-ballistic missile (ABM) weapons. Most of the early ASAT systems fell under the category of kinetic energy weapons (KEWs) which were based on the concept of hitting a satellite in orbit by a co-orbital weapon or a ground- or air-based missile.

First attempts to employ aircraft-borne ASAT missiles were made in the US in the late 1950s and early 1960s, as a part of programs to develop air-launched nuclear ballistic missiles. The B-47-launched ASAT missile tested in the Bold Orion program and the satellite interceptor (SAINT) program were two notable research and development efforts by the US military. In fact, an intercept conducted by the Bold Orion vehicle on 13 October 1959 was the world's first successful ASAT intercept with a missile. ${ }^{2}$

In 1962 the Soviet Union began the development of its most significant ground-based ASAT project Istrebitel Sputnikov (IS), or satellite killer, that used the R-36 super heavy ICBM as a booster. Once the satellite was detected, the missile was launched and after making one to two orbits, approached its target and exploded a shrapnel warhead close enough to destroy the spacecraft. The first successful test intercept was conducted in February 1970 and the system was declared operational in February 1973. The IS system was followed in the 1980s by a more advanced interceptor IS-MU that continued in operation until it was decommissioned in $1993 .{ }^{3}$

Remarkably, at that time even space nuclear explosions were considered as a possible means to counter an adversary's strategic ballistic missiles. However, both sides quickly realised that such explosions could cause immense collateral damage to satellites in orbit and to terrestrial installations, both military and civilian, so Moscow and Washington came to an agreement to abandon this idea. This agreement was reflected in the 1963 Test Ban Treaty banning nuclear weapon tests except for those conducted underground. It was signed by the governments of the Soviet Union, the United Kingdom, and the US in August 1963, and opened for signature by other countries. 
One of the early attempts to use outer space for attacking targets on the ground was the development by the Soviet Union of the Fractional Orbital Bombardment System (FOBS) that was based on the R36 ICBM, and was made operational in 1968 as R36 Orbital (R36-O). The FOB vehicle was to be launched from the Soviet Union, aimed due south into an elliptical, low-Earth orbit and to de-orbit at a prescribed point. It would then traverse southern polar areas circumventing the US ground-based early warning radar installations which were oriented to track Soviet ICBMs on trajectories over the North Pole, to strike the US via the "backdoor".

The FOBs major drawbacks were the need to wait for the right moment to deliver an effective strike at a prescribed target and the system's low reliability. This ultimately led to the US rejecting the idea of developing this type of space attack weapon. Instead, the view prevailed among the political and military leaders that a "classic" ICBM was a more reliable solution for ensuring nuclear deterrence. The 1979 Soviet-US Strategic Arms Limitation Treaty II (SALT II) strictly prohibited orbital nuclear bombardment systems, putting an end to further development of the Soviet FOBS. Accordingly, the R36-O missiles were decommissioned in January 1983. Similar provisions were also included in the 1991 Strategic Arms Reduction Treaty I (START I). ${ }^{5}$

Among the concepts the US tested and (for a brief time) deployed was the Nike Zeus AMB/ASAT weapons system developed during the late 1950s and early 1960s. While its two major versions were designed to intercept ICBMs in the upper atmosphere with a nuclear warhead, a third was produced and tested successfully for ASAT duties. From 1963 to 1966 Nike-Zeus ASAT missiles, which provided intercepts at altitudes of up to $250 \mathrm{~km}$, were deployed at the ABM test range in Kwajalein Atoll in the Pacific Ocean. About the same time, the US Air Force (USAF) had also deployed Thor intermediate-range ballistic missiles which were based at Johnston Island in the Pacific Ocean in an ASAT role. Despite performing the same mission, the two systems complemented each other, the Nike Zeus being a faster and more reactive missile, but limited by its range. The Thor was a slower and less agile missile due to its liquid propellants, but it had a much greater range of up to $700 \mathrm{~km} .{ }^{6}$

In addition to KEWs, research in the US was also focused on the systems based on directed electromagnetic energy, including a nuclear-explosion powered X-ray laser, and more conventional lasers including the idea of a satellite with a fixed laser and a deployable mirror for targeting. Those systems were sensitive to weather conditions and had limited range but among their advantages were the ability to attack a satellite target with varying intensity, just partly damaging its sensors or blinding it, whereas kinetickill weapons were designed to totally destroy their target. The facts about the US research on lasers were highlighted by Soviet propaganda, notwithstanding that from the 1970s onward the Soviet Union itself was actively involved in research and development of directed energy weapons. It experimented with large ground-based ASAT lasers that could pose a significant threat to both satellites and ballistic missiles. 


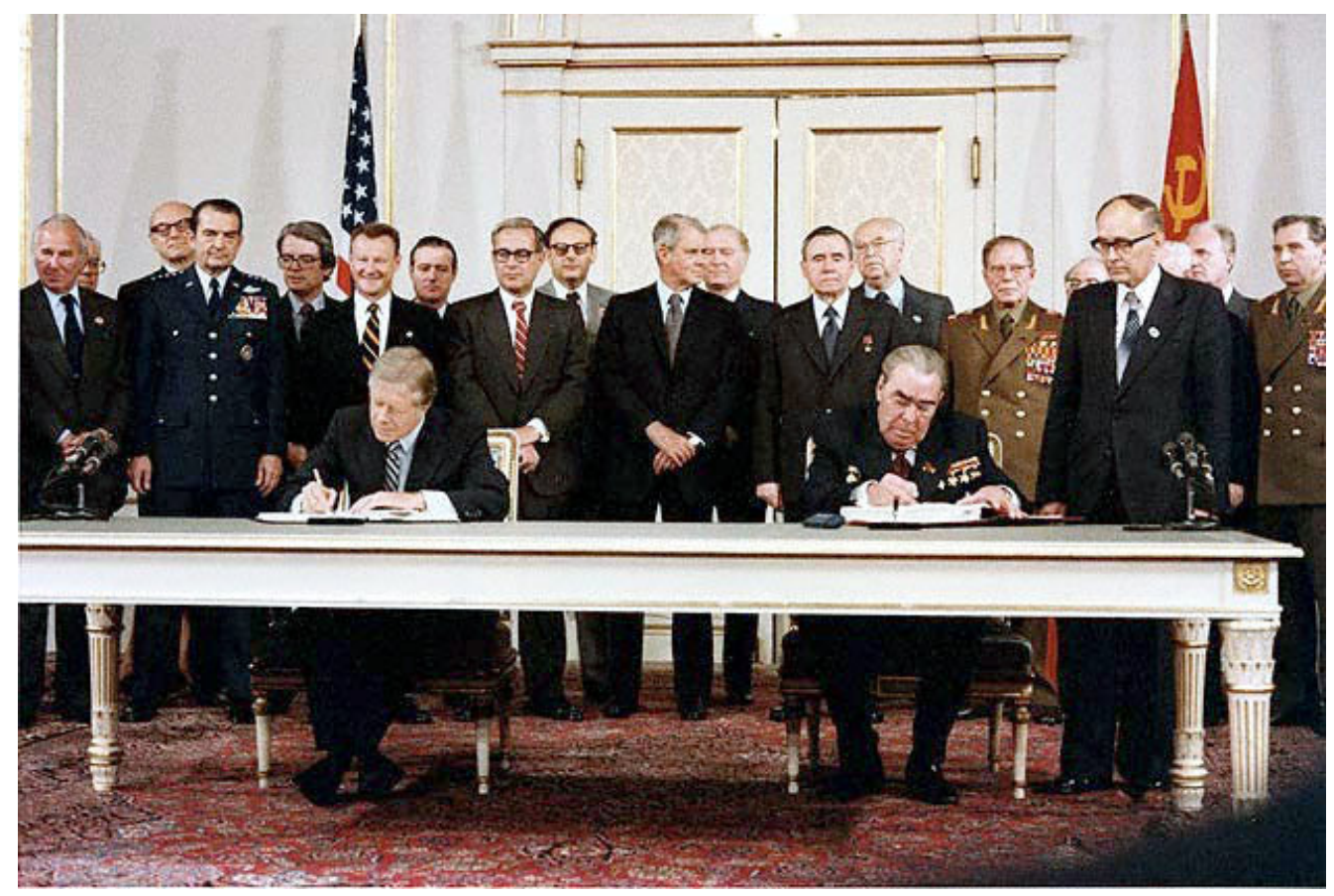

President Jimmy Carter and Soviet General Secretary Leonid Brezhnev sign the Strategic Arms Limitation Talks (SALT II) treaty, June 18, 1979, in Vienna. Source: US Government/Wikimedia Commons.

Since the mid-1980s, all Soviet space arms projects were structured to counter US President Ronald Reagan's Strategic Defense Initiative (SDI) that was planned to develop a space-based missile defense system to protect the US from a large-scale nuclear attack from Soviet ICBMs. It involved many layers of technology that had yet to be researched and developed. Among the potential components were both space-based and groundbased laser battle stations, air-based missile platforms and ground-based missiles using non-nuclear technologies for the interception of incoming missiles. As a result of the general lack of required technological infrastructure, and therefore somewhat fictional basis of the SDI, critics of the proposal nicknamed it "Star Wars" after the science fiction "Star Wars" movies which were box office hits around the same time.

In June 1982 the US was already planning to test a new-generation airborne ASAT weapon, the Air-Launched Miniature Vehicle (ALMV) which, in the opinion of the USAF, had significant advantages over ground-based systems. The ALMV system consisted of a small two-stage missile launched from an F-15 aircraft flying at high altitude. It carried a heat-seeking Miniature Homing Vehicle (MHV) which would ascend to a target satellite in low Earth orbit and destroy or disrupt it using the "hit-to-kill" method. From 1984 to 1986, the USAF carried out five flight tests within the ALMV program: 
twice in 1984, once in 1985 and twice in 1986. In three cases MHV interceptors were launched not against real orbital or suborbital targets, but "directed at a star", and in one further case the missile was "successfully tested" without the miniature kill vehicle.?

The first and only test against a space-borne target was performed in September 1985 against the decommissioned "Solwind -" P78-1 spacecraft, that was destroyed at an altitude of $525 \mathrm{~km} .{ }^{8}$ This test highlighted the adverse consequences of the ASAT system: the destroyed Solwind satellite generated several hundred pieces of space debris that could impact against and potentially destroy other space assets. The last piece of tracked debris from this test finally fell out of orbit in 2004.

In December 1985 the US Congress banned further testing of the ALMV system on satellites and in 1986 the ban on ASAT weapons tests was renewed. The Soviet Union continued to observe the voluntary moratorium on similar activities it had imposed at an earlier time. The following year the US agreed to extend the testing ban saying, however, that it would resume testing if Moscow did so. The Soviet Union, for its part, while honoring its testing moratorium, continued to pursue some missile defense and ASAT laboratory-based research. Reportedly, it was developing a similar ASAT weapon around this time, to be launched from a MiG-31 aircraft, but there is no evidence this project was pursued seriously.

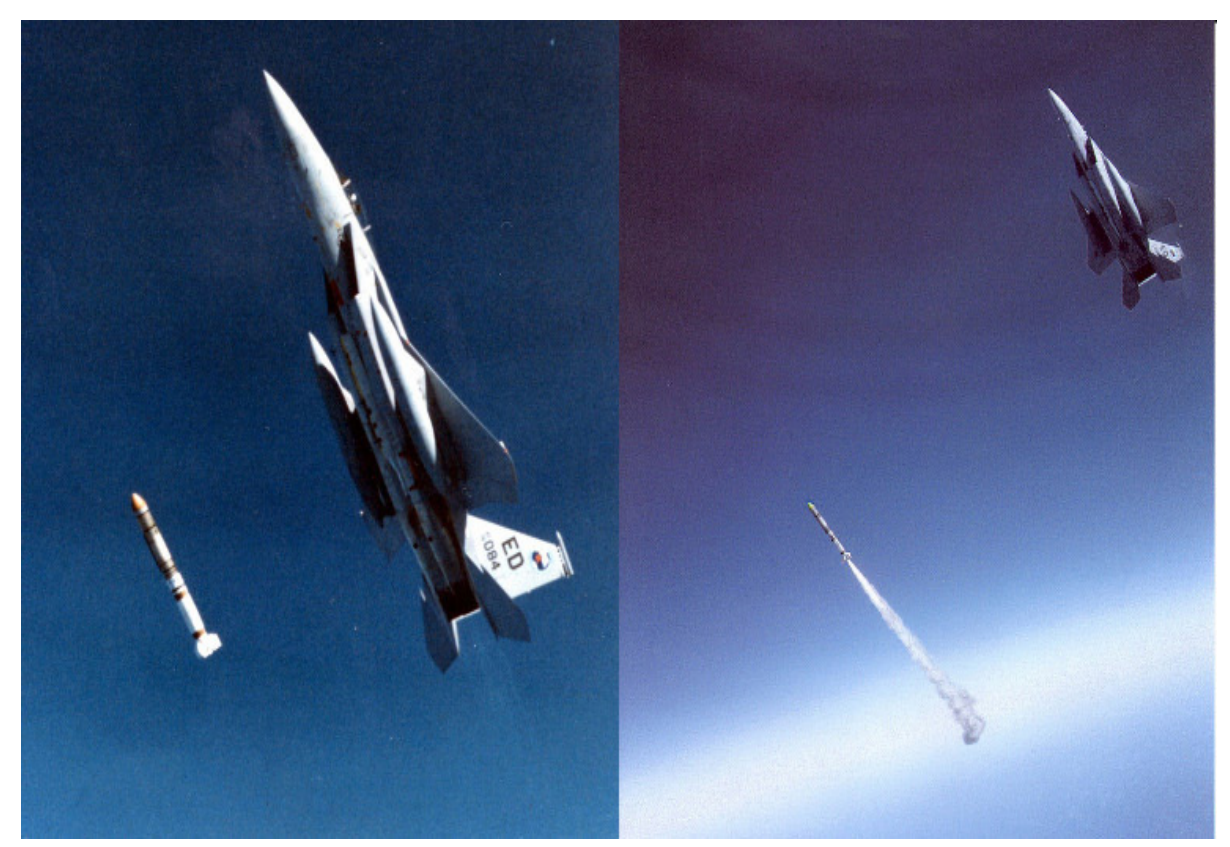

A collage of the ASAT test by a US F-15 fighter in 1985. Source: Wikimedia Commons 
The most recent case of use of the "hit-to-kill" ASAT by the US military occurred in February 2008 when the US Navy downed its own decommissioned reconnaissance satellite in low-Earth orbit at an altitude of $250 \mathrm{~km}$ by SM-3 ABM interceptor specifically designed for the AEGIS sea-based missile defense system. The remains of the spacecraft soon entered the dense layers of the Earth's atmosphere and quickly burned up. At these heights, objects only "live" between 1 to 4 days.

\section{China and India}

Since the 1980s China had been developing "hit-to-kill" technology as both an ASAT weapon and ballistic missile defence, and in January 2007, Beijing tested its first anti-satellite system, using a converted ICBM to hit its dead meteo-satellite "Feng Yun" at an altitude of $865 \mathrm{~km} .{ }^{9}$ The destruction created a cloud of more than 3,000 pieces of space debris, much of it will remain in orbit for decades, posing a significant collision threat to other space objects in Low-Earth orbit as at height of $600 \mathrm{~km}$ and above it takes up to 30 years for the remaining debris to come down and burn up in Earth's atmosphere. It was the first known successful satellite intercept test since 1985, when the US conducted a similar anti-satellite missile test.

At the end of March 2019, Indian Prime Minister Narendra Modi announced that New Delhi had successfully used a ballistic missile interceptor to destroy an orbiting satellite and stated that the country is now "an established space power." Along with this, Modi gave an assurance that India continued to maintain that "space should not be an area for warfare." ${ }^{10}$ Even so, India's successful ASAT test indicated that it was joining a short list of major players - China, the US and Russia - able to undertake a kinetic intercept of satellites in low Earth orbit.

The Russian Ministry of Foreign Affairs' statement on the Indian test underscored that "the one-sided and unlimited expansion of the global US missile defense systems, as well as the reluctance to abandon plans for putting weapons into space, make other states think about improving their own similar potentials in the interests of strengthening their national security." Concerned with the proliferation consequences this test could have, Russia offered India the opportunity to actively join the efforts of the international community developing a multilateral legally binding instrument for keeping outer space peaceful. ${ }^{11}$

Successive US administrations, invariably insisted on the necessity to maintain primacy and freedom of action in defending national interests in space, hardly ever disguising their view of space as an extension of military power. Notwithstanding the assertions on adherence to the principle of peaceful uses of space, US doctrinal documents on national security have always postulated the need to strengthen dominance in space. At times this has been nuanced, at other times more assertive, undulating from one presidency to another. 
Under the Presidency of George W. Bush, the 2006 US National Space Policy put forward its right to preserve "freedom of action in space and ... take those actions necessary to protect its space capabilities, respond to interference, and deny, if necessary, adversaries the use of space capabilities hostile to US national interests". The document also emphasized that "proposed arms control agreements or restrictions must not impair the rights of the United States to conduct research, development, testing, and operations or other activities in space for US national interests." ${ }^{12}$

The new National Space Policy released in July 2010 by the Obama administration, suggested that there would be a significant departure from the predecessor's standpoint. The document renounced the unilateral stance and emphasised international cooperation across a wide range of scientific exploration and national-security projects. It stated that the US would pursue bilateral and multilateral transparency and confidence-building measures (TCBM) and "consider proposals and concepts for arms control measures if they are equitable, effectively verifiable, and enhance the national security of the U.S. and its allies."13

However, the practical implications of the signaled change were less prominent. In the eyes of the Obama administration, the joint draft treaty on the Prevention of the Placement of Weapons in Outer Space (PPWT) introduced by Russia and China in 2008, was "fundamentally flawed" and could not provide any grounds for commencing negotiations. At the same time, the US supported the European Union's (EU) "Code of Conduct for Activities in Outer Space" advocating TCBMs as a better approach for improving space security. President Donald Trump's administration has gone further making clear that "any harmful interference with or an attack upon critical components of our space architecture that directly affects this vital US interest will be met with a deliberate response at a time, place, manner, and domain of our choosing." ${ }^{14}$

In December 2019, by signing the 2020 National Defense Authorization Act, President Trump brought into existence the Space Force as a sixth branch of the US Armed Forces "whose mission will be to organize, train, and equip combat space forces". ${ }^{15}$ Speaking on the occasion, Defence Secretary Mark Esper pointed out that "today outer space has evolved into a warfighting domain of its own" and that "maintaining American dominance in that domain is now the mission of the United States Space Force."16

According to the current US leadership's perspective, as outer space has become a mostly contested domain, US national security interests in space are facing growing serious challenges. The two major challengers are China and Russia. The Pentagon's Defense Intelligence Agency report released in February 2019, indicated, that China and Russia have developed counterspace capabilities ${ }^{17}$ that "threaten others' ability to use space", including ground-based missiles aimed at satellites, jamming of signals to or from satellites, ground-based directed energy weapons, kinetic-kill vehicles, and more. Both countries, emphasising the importance of space operations, have developed 
"robust and capable space services" including space-based intelligence, surveillance and reconnaissance, space launch vehicles and satellite navigation constellations. China established a strategic support force to integrate its space, cyberspace and electronic capabilities. The report also noted that Iran and North Korea have demonstrated emerging space capabilities. ${ }^{18}$

Analysing possible consequences of the formation of the US Space Force, the Russian leadership argued that an evolving armed rivalry in space, along with development of a space-based segment of missile defense, was unlikely to make outer space a less controversial or less dangerous environment and would have a grave destabilising effect on the geopolitical situation. In his remarks at a meeting with the defence officials on December 4, 2019, Russian President Vladimir Putin expressed his deep concern that the US considers outer space as a military theatre and that it is accelerating creation of its space forces "for preserving strategic supremacy". Accordingly, the world's leading countries are fast-tracking the development of modern military space systems and that Russia needed to do the same. ${ }^{19}$

In fact, Putin's comments reiterated those he made a few days earlier after NATO had declared space a fifth "operational domain" for the military alliance, alongside air, land, sea and cyber. The comments came, notwithstanding the NATO Secretary General's assurances that "the Alliance has no intention to put weapons into space and its approach to space will remain fully in line with international law."20

Recently, the dispute between Russia and the US over the space security issue has intensified. In a statement of 15 April 2020, the US Space Command implied that Russia had conducted a "direct-ascent" anti-satellite test that showed that Russia's missiles were capable of destroying satellites in low Earth orbit. The Space Command regarded this as providing "yet another example that the threats to US and allied space systems are real, serious and growing" and that the launch testifies, in the US view, "to the hypocrisy of the Russian authorities promoting an initiative to prevent the militarisation of outer space." ${ }^{21}$

The details of the direct-ascent anti-satellite test were not disclosed by Russia. However, experts believe that most likely this was the launch of the "Nudol" ballistic missile interceptor initially developed and tested as an element of the modernized A-235 Moscow ABM defence system. In the 1990s, development of this project was temporarily discontinued, but beginning in 2011, the "Nudol" direct-accent ASAT system, which is likely an offshoot of the A-235, has been under development and testing. In relation to the April test the interceptor was equipped with a dummy kill vehicle and firing was not carried out on a real target, as previous ASAT tests by India, China and the US have been..$^{22}$ 
Earlier in April, the US Assistant Secretary of State for International Security and Non-Proliferation, Christopher Ford, delivered a keynote address on the military aspects of space exploration, raising a number of complaints against Russia and China, sharply criticising both countries for "irresponsible actions that obviously represent quite a remarkable and provocative escalation of military posture in outer space, ... demonstrate the dangerous degree to which Moscow and Beijing have already weaponised the space domain in threatening ways" (emphasis in the original), developing and deploying the latest anti-satellite missiles. ${ }^{23}$

Responding to the above accusations, Sergei Ryabkov, Russian Deputy Foreign Minister, pointed out that the problems arose due to the fact that the US "has been shaking strategic stability in various aspects for a long time and is rapidly preparing to deploy strike assets in outer space, including for missile defense". Ryabkov, however, assured that "we will continue the work there to bring to our American colleagues the logic according to which space is not a sphere where it is possible to impose your ideas and concepts on the entire international community." ${ }^{24}$ Notably, it became known about the same time, that the parties agreed as part of the Russian-American Strategic Dialogue to set up an ad hoc working group on outer space to substantively discuss space security issues. This step looks absolutely reasonable, as the safe and unimpeded use of outer space has become an utmost priority of the international security agenda.

The global community relies ever more on space-based technology for defence, civil, scientific and commercial purposes. Indeed, space is becoming more and more a congested and competitive domain, and the potential threat to space objects is growing. It seems appropriate to briefly dwell here on the character of geopolitical and geo-economic effect that, from Moscow's standpoint, may occur should the plans to weaponise space be realised. Certainly, the list of potential consequences and threats is far from exhaustive but the most significant are listed below:

- the existing international security architecture would be undermined, the world would be pushed towards a new arms race, and not only in outer space, thus negating decades of efforts to reduce confrontation, curb the arms race and prevent proliferation of WMD and rocket means of delivery;

- any attempt by the US to implement such scenario would represent a deliberate intention to achieve a unilateral military superiority, using a space attack system, if developed, tested and deployed, as a new, extremely destabilising type of strategic weaponry;

- the fundamental principles of the peaceful outer space exploration that have been ruling space activities of all states for six decades would be compromised, outer space would be turned into an arena of military stand-off making useless further dialogue on strengthening space security in the interests of humankind; 
- plans to deploy attack weapons in space would be inevitably regarded by other space-faring nations as a threat of intentional interference, states would be encouraged to actively seek various kinds of "mirror", "symmetric" or "asymmetric" responses to emerging threats to their national security and their space activity;

- implementation of such plans may well be regarded as an infringement of national security and sovereignty, an attack on space assets would be regarded as an act of direct aggression;

- development, testing and deployment of anti-missile and anti-satellite assets in space will stimulate use of a variety of protection systems that would greatly raise the cost of already expensive space exploration projects and force a number of nations to abandon or degrade their ongoing space programs.

- placing weapons in outer space could require launching new, multiple spacecraft into low-Earth orbit (400-1,500 km), necessitating intensive maintenance work, which will inevitably lead to a sharp increase in orbit of the amount of "space debris" threatening spacecraft of all countries operating in near-Earth space, including manned missions.

\section{Creating an international legal regime: Initiatives to prevent the weaponisation of space}

In the early 1960s there was a bilateral recognition that unimpeded development and deployment of the weapon systems in space was not in either superpower's best national interest. This slowed down the dangerous trend of turning this type of weaponry into a dangerous and destabilising factor for global security and pushed the Soviet Union and the US to take the first steps in space arms control. This was reflected in multilateral and bilateral legal norms dealing with the weaponisation of space issue directly or indirectly, as topics of discussion or formalised as agreements.

Following the 1963 Partial Test Ban Treaty, a historic agreement that outlawed nuclear testing in the atmosphere, underwater, and in outer space, the international diplomacy in the course of two decades had successfully created a system of multilateral treaties establishing the international legal regime for outer space, including the celestial bodies. The international space law code comprises five legal instruments ${ }^{25}$ supplemented by five UN General Assembly resolutions ${ }^{26}$ that were based on the fundamental rules of space use.

Initially summarised in the 1963 UN "Declaration of Legal Principles Governing the Activities of States in the Exploration and Use of Outer Space" the principles announced outer space as the common heritage of humankind, open to research and peaceful uses for the benefit of all countries without any discrimination, regardless of their economic and scientific development, and regulated the rights and obligations of participants 
in space activities. Activities in outer space and on celestial bodies were to be carried out in accordance with international law, including the United Nations Charter, in the interest of maintaining international peace and security and promoting international cooperation and understanding. As time passed, all subsequent treaties relating to international space law included most of the principles set out in this Declaration. ${ }^{27}$

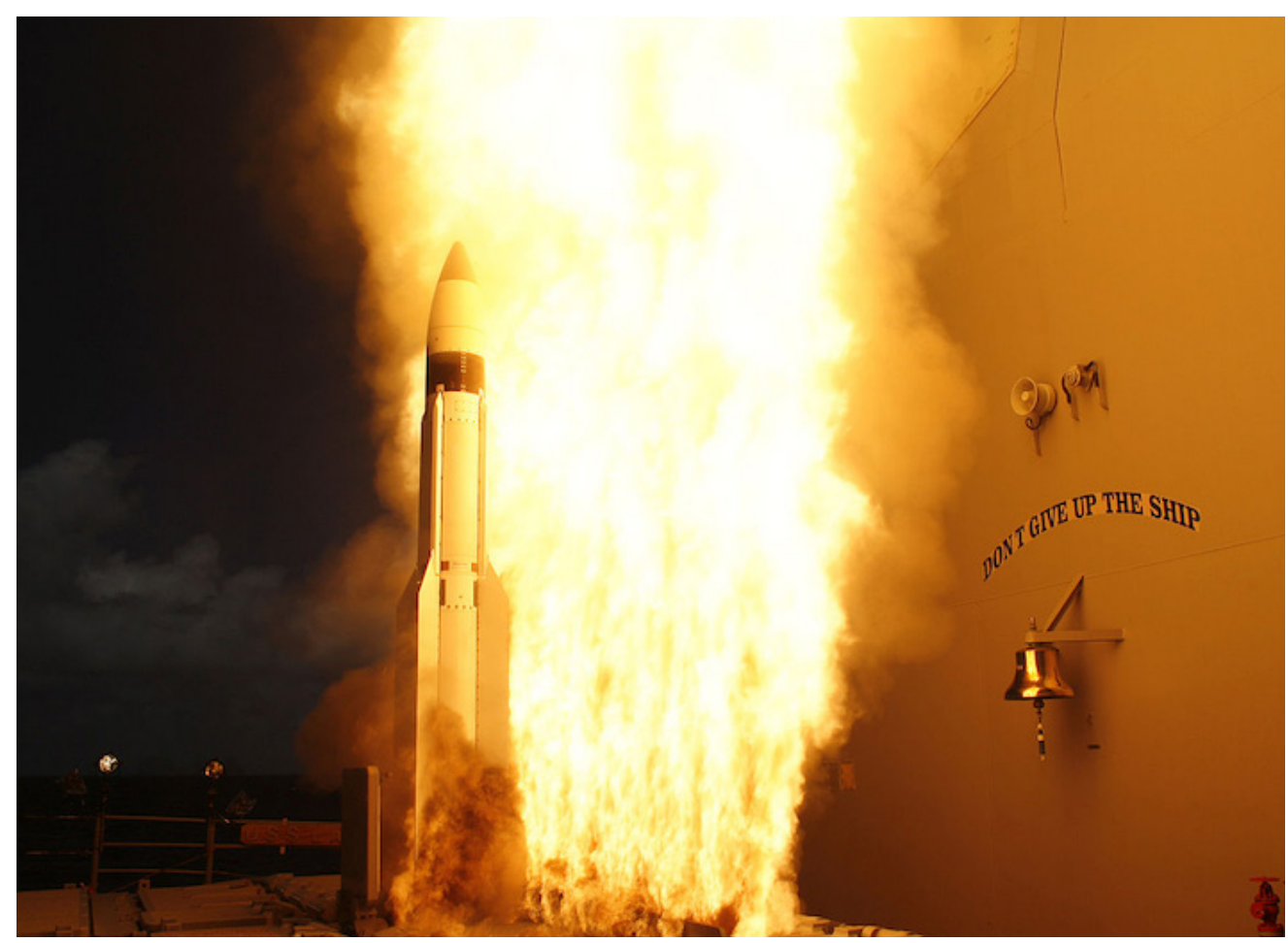

A Standard Missile-3 (SM-3) is launched from the guided missile cruiser USS Lake Erie during a joint Missile Defense Agency, U.S. Navy ballistic missile flight test. Source: US Navy/Wikimedia Commons.

The most significant international agreement was the 1967 Treaty on Principles Governing the Activities of States in the Exploration and Use of Outer Space, including the Moon and Other Celestial Bodies, or Outer Space Treaty. This became a kind of "space constitution," governing peaceful space activities of all nations, providing the general legal basis and a framework for further development of "space law."

According to Article 4 of the 1967 Treaty, the Parties undertake "not to place in orbit any objects carrying nuclear weapons or any other kinds of weapons of mass destruction, install such weapons on celestial bodies, or station such weapons in outer space in any other manner." It states that "the Moon and other celestial bodies shall be used by 
all States Parties to the Treaty exclusively for peaceful purposes" and expressly forbids "establishment of military bases, installations and fortifications, the testing of any type of weapons and the conduct of military maneuvers on celestial bodies."28

Following the adoption the Partial Test Ban Treaty and the Outer Space Treaty, the Soviet Union and the US took the third, though rather indirect, step in space arms control, signing in 1972 the Treaty on the Limitation of Anti-Ballistic Missile Systems (ABM Treaty). This document formally dealt with the ground-based and space-based missile defense systems and components. At the same time, it had a strong anti-ASAT connotation and potential, extending protection to either country's "national technical means of verification," i.e. early warning and reconnaissance satellites launched for verifying treaty compliance. ${ }^{29}$

The ABM Treaty alongside the Strategic Arms Limitation Treaty (SALT 1) also signed on 26 May 1972, became the first international legal codification of military nondestructive support systems in orbit. The concept of non-interference with national technical means of verification of the arms control regimes compliance was also taken over into the 1987 Intermediate Range Nuclear Forces (INF) Treaty and appeared in subsequent US-Soviet Union/Russia arms control treaties. This obligation was made multilateral in the 1990 Conventional Forces in Europe (CFE) Treaty.

It should be noted that the prohibitions on the use of weapons in outer space set forth in the norms of the international space law are not comprehensive in nature, but only apply to weapons of mass destruction (WMD). Thus, the 1967 Outer Space Treaty does not ban placement of conventional weapons in near-Earth orbit, and only the Moon and other celestial bodies and near-Earth orbit are excluded from military activities. ${ }^{30}$ None of the agreements contains a universally accepted definition of "space weapons", "weapons in outer space", "use of force" or "threat of force." That is the main reason why many states (including Russia) keep arguing that existing legal instruments are insufficient for safeguarding freedom of exploring outer space as "the common heritage of mankind."

In 1981 and again in 1983 the Soviet Union was the first country to introduce to the United Nations a draft treaty calling for a ban on all existing ASAT systems and banning deployment of weapons of any kind in outer space. The US refused to participate in multilateral negotiation on either the 1981 or 1983 draft treaties, claiming the Soviet initiatives were mere propaganda to turn the world public opinion against President Ronald Reagan's SDI, and inhibit the progress of this program. In its turn, Moscow branded the SDI a clear violation of the 1972 ABM Treaty that had committed the US and the Soviet Union to refrain from developing space-based missile defence systems while limiting ground-based $\mathrm{ABM}$ assets in order to prevent a new and costly arms race. 
Around that time, the Soviet Union and the US were deeply engaged in discussing the mandate for the arms control negotiations, whether or not to include the issue of preventing the weaponisation of outer space, alongside the general issues related to strategic and intermediate systems. In January 1985 an agreement was reached at the meeting of the US Secretary State George Shultz and Soviet Foreign Minister Andrei Gromyko to discuss the issue of an arms race in space along with intermediate-range nuclear forces and strategic arms reductions. Nuclear and Space Talks started in May 1985, resulting in adoption of the INF Treaty in 1987, and START I Treaty in 1991.

However, despite the historic break-through in the nuclear and missile disarmament, the Soviet proposal calling for prevention of an arms race in space and Reagan's cherished SDI remained incompatible throughout the talks. The two sides ultimately could not come to an agreement and they finally ceased addressing the issue of space weapons.

With the collapse of the Soviet Union, bilateral negotiations over the space security came to a halt. In the early 1990s the Russian Federation and the US put forward a few related initiatives, such as the concept of a Global Protection System against missile threat, announced at the US-Russia summit in June 1992 that was based on President H.W. Bush's concept of the Global Protection Against Limited Strike. In the meantime, the US initiated a further transformation of the national ballistic missile defence program that involved the demand to "update" the ABM Treaty and culminated on 1 September 2000, when President Clinton announced the development of a limited National Missile Defence system. This brought to a halt any further joint activity, and Washington's unilateral withdrawal from the ABM Treaty in 2002 left little hope that new bilateral space-related arms control negotiations would occur in the post-Cold War era.

With the failure of the superpowers' effort to address the weaponisation of space in the bilateral format, the issue was moved to multilateral forums. From Moscow's perspective, there could be no better platform for working out appropriate international legal regulators preventing an arms race in space than existing UN mechanisms, which have proved their effectiveness previously at times of intensive development of space law norms.

Since the early 1980s, the UN Conference on Disarmament (UNCD), the world's only permanent multilateral disarmament issues negotiating body, was mandated to hold negotiations under the agenda item "prevention of an arms race in outer space" (PAROS), including draft treaties aimed at preventing the placement of weapons in outer space and prohibiting the use of anti-satellite weapons. The issues that have arisen in the PAROS format have also been discussed in the UN General Assembly First and Fourth committees, and the Committee on the Peaceful Uses of Outer Space (COPUOS), among others. 
In 1985, the UNCD established an ad hoc committee to identify and examine issues relevant to PAROS such as the legal protection of satellites, nuclear power systems in space, and various confidence-building measures. The US consistently refused to negotiate PAROS in the UNCD. Finally, discussions about PAROS in UNCD came to a standstill in 1995, when China insisted on linking PAROS to the Fissile Material Cut-off Treaty, which was considered unacceptable by Washington. Soon after that China and the Russian Federation proposed to advance negotiations on a jointly submitted draft treaty on preventing the weaponisation of outer space. Among other multilateral efforts aimed at achieving tangible progress in tackling the PAROS issue was the initiative to adopt measures to improve and ensure transparency and build confidence in outer space activities, put forward by the Russian Federation in UN General Assembly sessions since 2005 that enjoyed support from an overwhelming majority.

In 2004, trying to make progress, Russia undertook a unilateral political commitment not to be the first state to deploy weapons in space. Washington refused to support this step. Further, such commitment has been recorded in the joint communiques of the Russian Federation with various countries demonstrating its adherence to the policies of transparency and mutual trust in space.

In 2010, the UN General Assembly made renewed efforts on PAROS establishing a Group of Governmental Experts (GGE) on Transparency and Confidence Building Measures for Outer Space Activities to conduct a study starting in 2012. In 2017 the GGE was reestablished with the mandate to consider and make recommendations on substantial elements of a future international legally binding instrument on the prevention of an arms race in outer space.

Russia and China have, despite the UNCD's deadlock, continued to push for the UNCD to negotiate measures related to PAROS. In 2002, they submitted a joint working paper on "Possible Elements for a Future International Legal Agreement on the Prevention of the Deployment of Weapons in Outer Space, the Threat or Use of Force Against Outer Space Objects." Further on in 2008, both countries officially submitted a draft treaty in Geneva. It was the first "full-size" draft of a legal document of this nature since 1983, called the "Treaty on the Prevention of the Placement of Weapons in Outer Space, the Threat or Use of Force against Outer Space Objects" (PPWT). The PPWT explicitly obliged the parties "not to place in orbit around the Earth any objects carrying any kind of weapons, not to install such weapons on celestial bodies, and not to station such weapons in outer space in any other manner". The draft contained basic definitions of "weapons in outer space", what would be considered as "a weapon 'placed' in outer space", what actions should be considered as "use of force" or "threat of force", etc. It also reiterated the realisation by the Parties of the sovereign right to self-defense in accordance with Article 51 of the UN Charter and included a clause on confidence-building measures to "facilitate assurance of compliance with the Treaty provisions and to promote transparency."31 
In June 2014 Russia and China resubmitted an updated draft of the Treaty that included the amended definitions of basic terms, and proposals put forward by the interested states that sought to address objections and agree on compromises. ${ }^{32}$ Discussions on this issue have shown that the majority of countries supported the concept of the PPWT, though its further consideration has been hampered by the negative attitude on the part of the US and a few others. The George. W. Bush administration dismissed the proposal, while the Obama and the Trump administrations have continued to reject this draft treaty as well.

Presenting the US position on the new PPWT draft in August 2014, US Ambassador to the Conference on Disarmament Robert Wood cited a number of issues with the draft treaty, that he called "the fundamental flaws in the PPWT', among them the lack of a verification mechanism and no restrictions on the development and stockpiling of the "terrestrially-based ASAT systems" that are "the most pressing existing threat to outer space systems." ${ }^{33}$

Since then, the US approach towards the development of new norms preventing an arms race in space in general, and on the PPWT draft in particular, has basically remained unchanged. Speaking on the PPWT issue in August of 2019, Ambassador Wood repeated that the "fundamentally flawed" PPWT would not be "the solution to the many threats facing the space environment" and that the peaceful uses of outer space should be pursued through bilateral and multilateral transparency and voluntary confidence-building measures, "development and advancement of norms of behavior in outer space and best practices for space operations". As Wood said in his remarks, "the United States is willing to consider space arms control proposals and concepts that are equitable, effectively verifiable, and enhance the security of all nations... However, we have not yet seen any legally-binding proposals that meet these criteria." 34

Since 2008, in an effort to enhance the safety, security and sustainability of space activities, the European Union has been advancing a draft "International Code of Conduct for Activities in Outer Space" (the Code), as a legally non-binding "soft law" instrument, containing a set of rules for ensuring security of space exploration. The main purpose of the Code is strengthening existing UN treaties, principles and other arrangements and complement them by codifying new best practices in space operations, including notification and consultation. This should consolidate confidence and transparency among the space actors. There is an understanding between Russia and the EU on the distinction between the subject matter and legal status of the Code and the PPWT, since the European initiative does not address the issues of preventing the deployment of weapons in space, which are the subject of the PPWT draft. Despite such divergence, the Code can be seen as an important stepping-stone toward an international treaty. ${ }^{35}$ 
In January 2012, the US announced it would work with the EU to advance the Code, considering it as a sufficiently good foundation for developing an international arrangement based on voluntary confidence-building measures helping to prevent accidents and mistrust in outer space. In his abovementioned remarks, Ambassador Wood emphasised the use of nonbinding agreements encouraging transparency and confidence-building mechanisms as a better approach for improving space security.

Significant discussions on the PAROS issue in preceding decades in the UN and other forums have defined areas of controversy, as well as identified common interests on which most states could agree. From Moscow's viewpoint, the multinational effort towards this goal must be continued in encouraging political momentum to support the joint efforts of politicians, diplomats and military experts to work out an international legal regulation of the remaining "grey" zone of definitions and terminology. Such an approach would have been a more effective and a far less laborious solution compared to lengthy and complex negotiations to reduce and eliminate weapons already deployed.

The above-quoted statement by the US Assistant Secretary of State Christopher Ford might suggest a welcome departure from a rather rigid approach demonstrated by the US in the Geneva Conference debates. Ford rather traditionally rejected the Russian-China initiative, branding it a "dangerous and hypocritical" attempt "to constrain the United States and our allies without either Moscow or Beijing having the slightest intention of abiding by the commitments they are proffering." But he positively evaluated the work on PAROS done by the EU with the Code by the UN Committee on Peaceful Uses of Outer Space and the Group of Governmental Experts. Most importantly, according to Ford, "the U.S. diplomats are looking, in other words, to work constructively with their counterparts in other spacefaring nations to develop approaches to outer space norms." ${ }^{36}$ Perhaps, opening consultations on space security within the RussianAmerican Strategic Dialogue between the Russian Ministry of Foreign Relations and the US Department of State, would be a good lead towards resuming mutual effort to prevent an arms race in outer space, no matter how ambitious such assumption might look for the current situation in the Russian-US relations.

In Russia's opinion, the PPWT draft, or basic elements of it, could serve as a good starting point for developing a future legally binding international norm. Over the years, Russia and China have proposed initiatives to address the issue of PAROS, and the key one is the PPWT draft. Both major spacefaring nations would strongly object to any attempt to off-handedly dismiss it. It has been repeatedly tabled as an official negotiating document on space non-weaponisation and received strong support from a majority of the UN member-states. Once the PPWT becomes the subject of formal discussions, be it in bilateral or trilateral consultations, or within the UN format, it could merge into a commonly acceptable plan or road map for how to move forward towards a future diplomatic solution of the space arms control problem. 
1 'The Military Doctrine of the Russian Federation,' 29 June 2015, The Embassy of the Russian Federation to the Kingdom of Great Britain and Northern Ireland. Available at: https://rusemb.org.uk/ press/2029.

2 'Bold Orion' Weapons System 199 (WS-199B)', n.d. Available at https://www.globalsecurity.org/space/systems/bold-orion.htm

3 Information on the Soviet/Russian IS program available at http://www.russianspaceweb. com/is.html

4 Braxton Brick Eisel, "The FOBS of War," AIRFORCE Magazine, 1 June 2005. Available at https:// www.airforcemag.com/article/0605fobs/

5 "The Treaty between the United States of America and the Union of Soviet Socialist Republics on the Reduction and Limitation of Strategic Offensive Arms and Associated Documents."

Available at https://fas.org/nuke/control/start1/text/treatytc.htm\#TREATYTOC

6 Matthew Mowthorpe, The Militarization and Weaponization of Space, (Washington DC, Lexington, 2004), pp.111-112.

7 Laura Grego, “A History of Anti-Satellite Programs," Union of Concerned Scientists. January 2012.

Available at https://www.ucsusa.org/sites/default/files/2019-09/a-history-of-ASAT-programs_lo-res.pdf

8 Ibid.

9 Geoffrey Forden, "After China's Test: Time For a Limited Ban on Anti-Satellite Weapons," Arms Control Association, n.d. Available at https://www.armscontrol.org/act/2007-04/features/after-chinas-test-time-limited-ban-anti-satellite-weapons

10 Kelsey Davenport, "Indian ASAT test raises space risks," Arms Control Association, May 2019. Available at https://www.armscontrol.org/act/2019-05/news/indian-asat-test-raisesspace-risks

1111 Andrew Korybko, "Russia's Response to India's ASAT Missile Test Wasn't What New Delhi Expected," Global Search, April 1, 2019. Available at https://www.globalresearch.ca/ russias-response-to-indias-asat-missile-test-wasnt-what-new-delhi-expected/5673254

12 "National Space Policy of the United States of America," released on 6 October 2006. Available at https://www.globalsecurity.org/jhtml/jframe.html\#https://www.globalsecurity.org/space/library/policy/ national/us- space-policy_060831.pdf

13 "National Space Policy of the United States of America," released on 28 June 2010. Available at https://www.globalsecurity.org/jhtml/jframe.html\#https://www.globalsecurity.org/ space/library/policy/national/100628_national_space_policy.pdf|||

14 "National Security Strategy of the United States of America", issued on December 18, 2017. Available at https://www.whitehouse.gov/wp-content/uploads/2017/12/NSS-Final-12-18-2017-0905.pdf

15 "President Donald J. Trump is Launching America's Space Force," White House Fact Sheet, 23 October 2018. Available at https://Www.whitehouse.gov/briefings-statements/president-donald-j-trump-launching-americas-space-force/

16 "Trump signs defense bill establishing U.S. Space Force: What comes next" by Sandra Erwin. "Space News", December 20, 2019. Available at https://spacenews.com/trump-signsdefense-bill-establishing-u-s-space-force-what-comes-next)

17 In the US Air Force vocabulary, counterspace is a mission, like counterair, that integrates offensive and defensive operations to attain and maintain the desired control and protection in and through outer space.

18 "Challenges to Security in Space," [US] Defense Intelligence Agency, 2019. Available at https://media.defense.gov/2019/Feb/11/2002088710/-1/-1/1/SPACE-SECURITY-CHALLENGES.PDF

19 "Putin urges greater attention to strengthening orbital group of satellites," TASS, 5 December 2019. Available at https://tass.com/science/1095757

20 "Foreign Ministers take decisions to adapt NATO, recognize space as an operational domain," NATO, 20 November 2019. Available at https://www.nato.int/cps/en/natohq/news_171028.htm

21 “U.S. Space Command blasts Russia for anti-satellite missile test," Space News, 15 April 2020. Available at https://spacenews.com/u-s-space-command-blasts-russia-for-anti-satellite-missile-test/ 
22 "Russia's ASAT development takes aim at LEO assets" by Jane's Intelligence Review. Available at ,https://www.janes.com/images/assets/591/81591/Russias_ASAT_development takes_aim_at_LEO_assets_v2.pdf

23 Christopher Ashley Ford, "Whither Arms Control in Outer Space? Space Threats, Space Hypocrisy, and the Hope of Space Norms," Center for Strategic and International Studies, 6 April 2020. Available at https://ww w.state.gov/whither-arms-control-in-outer-space-space-threats-space-hypocrisy-and-the-hopeof-space-norms/

24 "U.S. and Russia Trade Accusation of Space Militarization, to Organize Work Group, 'South Front', April 17, 2020. Available at https://southfront.org/u-s-and-russia-trade-accusation-of-space-militarization-to-organize-work-group/

25 1. Treaty on Principles Governing the Activities of States in the Exploration and Use of Outer Space, including the Moon and Other Celestial Bodies - entered into force on 10 October 1967;

2. Agreement on the Rescue of Astronauts, the Return of Astronauts and the Return of Objects Launched into Outer Space - entered into force on 3 December 1968;

3. Convention on International Liability for Damage Caused by Space Objects - entered into force on 1 Sept 1972;

4. Convention on Registration of Objects Launched into Outer Space - entered into force on 15 September 1976;

5. Agreement Governing the Activities of States on the Moon and Other Celestial Bodies - entered into force on 11 July 1984.

26 Declaration of Legal Principles Governing the Activities of States in the Exploration and Use of Outer Space, adopted on 13 December 1963, Principles Governing the Use by States of Artificial Earth Satellites for International Direct Television; Broadcasting, adopted on 10 December 1982; Principles Relating to Remote Sensing of the Earth from Outer Space, adopted on 3 December 1986, Principles Relevant to the Use of Nuclear Power Sources in Outer Space, adopted on 14 December 1992, Declaration on International Cooperation in the Exploration and Use of Outer Space for the Benefit and in the Interest of All States, Taking into Particular Account the Needs of Developing Countries, adopted on 13 December 1996.

27 UN OFFICE FOR OUTER SPACE AFFAIRS. "International Space Law: United Nations Instruments". Available at https://www.unoosa.org/res/oosadoc/data/documents/2017/stspace/ stspace61rev_2_0_html/V1605998-ENGLISH. pdf pp.45-47.

28 UN OFFICE FOR OUTER SPACE AFFAIRS. "International Space Law: United Nations Instruments". Available at https://www.unoosa.org/res/oosadoc/data/documents/2017/stspace/stspace61rev_2_0 html/V1605998-ENGLISH.pdf, p.5

29 "TREATY BETWEEN THE UNITED STATES OF AMERICA AND THE UNION OF SOVIET SOCIALIST REPUBLICS ON THE LIMITA TION OF ANTI-BALLISTIC MIS-

SILE SYSTEMS”. Available at https://treaties.un.org/doc/Publication/UNTS/Volume\%20944/ volume-944-I-13446-English.pdf

30 For example, the Treaty did not outlaw systems designed to deliver WMD into Earth's orbit, thus, allowing the Soviet FOB system in its developmental phase not to be formally considered as a violation of the Treaty regime as long as it was not equipped with a nuclear warhead.

31 "Conference on Disarmament Documents related to Prevention of an Arms Race in Outer Space". Available at https://documents-dds-ny.un.org/doc/UNDOC/GEN/G08/604/02/PDF/ G0860402.pdf?OpenElement

32 "Treaty on the Prevention of the Placement of Weapons in Outer Space, the Threat or Use of Force against Outer Space Objects(Draft)," Ministry of Foreign Affairs of the People's Republic of China, 16 June 2014. Available at https://www.fmprc.gov.cn/mfa_eng/wjb_663304/ zzjg_663340/jks_665232/kjfywj_665252/t1165762.shtml

33 "U.S. Dismisses Space Weapons Treaty Proposal As "Fundamentally Flawed"," Space News, 11 September 2014. Available at https://spacenews.com/41842us-dismisses-space-weapons-treaty-proposal-as-fundamentally-flawed/

34 "Statement by Ambassador Wood: The Threats Posed by Russia and China to Security of the Outer Space Environment," US Mission to International Organizations in Geneva, 14 August 2019. Available at https://geneva.usmission.gov/2019/08/14/statement-by-ambassadorwood-the-threats-posed-by-russia-and-china-to-security-of-the-outer-space-environment/ 
35 "Draft International Code of Conduct for Outer Space Activities: Fact Sheet," Secure World Foundation, February 2014. Available at https://swfound.org/media/166384/swf draft international_code_of_conduct_for_outer_space_activities_fact_sheet_february_2014.p.pdf 36 Christopher Ashley Ford, "Whither Arms $\bar{C}^{-}$ontrol in Outer Space? Space Threats, Space Hypocrisy, and the Hope of Space Norms," Center for Strategic and International Studies, 6 April 2020. Available at https://ww w.state.gov/whither-arms-control-in-outer-space-space-threats-space-hypocrisy-and-the-hopeof-space-norms 
